\title{
Ezra Henry Moss, 1892-1963
}

by C. D. Bird, University of Alberta, Calgary

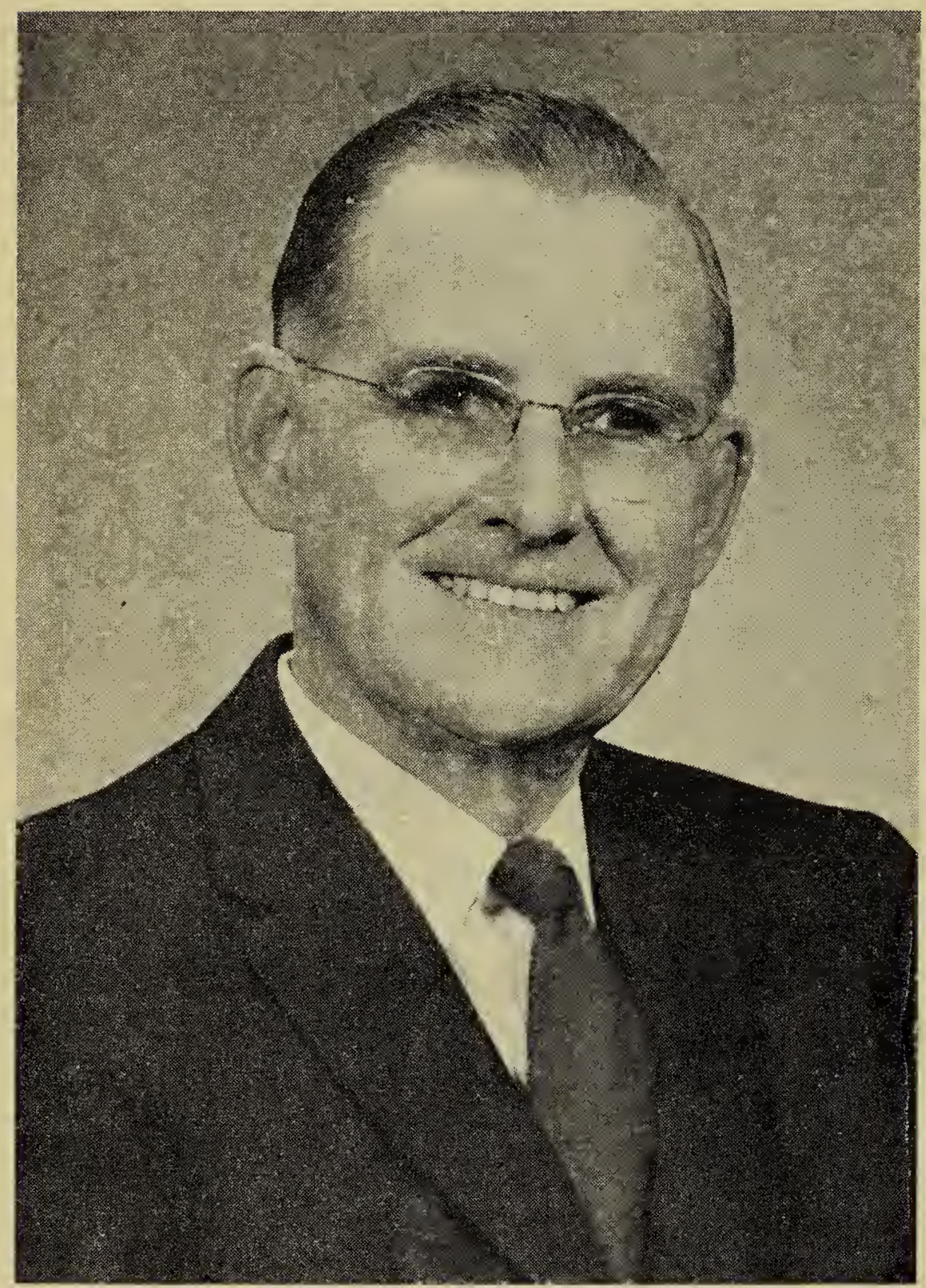

scattered collections, but their work was only exploratory in nature. The first organized attempt to describe the vegetation of the region was initiated by $F$. J. Lewis the first Head of the Department of Botany of the University of Alberta, who started a series of papers entitled "The Vegetation of Alberta." The second part of this project, on the swamp, moor and bog forest vegetation of central Alberta, was published in 1928 with E. S. Dowding and E. H. Moss as co-authors. The fourth part, with E. H. Moss as sole author, was devoted to the poplar association of central Alberta and appeared in 1932. Further installments, all by Dr. Moss, were on the prairie region of southwestern Alberta (1944), the vegetation of the Peace River region (1952), and that of northwestern A l b e r t a (1953). All Alberta vegetational studies were summarized in 1955 in a

Canadian botanists have lost a friend and a truly great pioneer with the passing of Dr. E. H. Moss of Edmonton on February 7,.1963.

Born in 1892 at Thorndale, Ontario, Dr. Moss earned the Military Medal for service in the First World War. After obtaining his Ph.D. degree at the University of Toronto in 1925 he joined the staff of the Department of Botany at the University of Alberta, Edmonton, in 1929. In 1938 he was elevated to the rank of full Professor and became head of the Department. He retired in 1957 and at that time was further elevated to the rank of Professor Emeritus.

Prior to his arrival on the Alberta scene little botanical work had been done in the province. A few workers in the nineteenth century, namely Thomas Drummond, Eugene Bourgeau and John Macoun, had made paper that appeared in the Botanical Review.

Along with his vegetational studies Dr. Moss collected, and was interested in, the vascular plants. Over 10,000 sheets of his material are represented in the. University Herbarium in Edmonton. These specimens and those of other botanists who had worked in the area formed the basis of his "Flora of Alberta," the first flora ever to have been written for the province. This work has been very favorably received and the following review from The American Midland Naturalist is typical: "The publication of Flora of Alberta is a major event in North American floristic botany ... a highly valuable, taxonomically up-to-date, and much needed work."

Although Dr. Moss's interests were mainly in vegetational description and 
floristic taxonomy he has also published significant studies on the fungi, the bryophytes, and on plant anatomy. His personal collections of fungi and part of his collections of the bryophytes will be deposited at the University Herbarium in Edmonton. The remainder of the bryophytes will go to the University of Alberta, Calgary.

Not the least of his contributions was the encouragement and ready help that he gave to his colleagues, amateur and professional alike. Among those that blossomed with this aid were such non-professionals as A. H. Brinkman, W. C. McCalla, G. H. Turner and George Pegg, all ff whom have made important conributions.

Long to be remembered are the nany stimulating talks and educaional field trips I have had with im. The last excursion we made tosether was a two-day trip in July, 962 , into the Sunshine area and nnow Creek Pass of Banff National ark. He was still remarkably agile nd was making extensive collections vith the view in mind of revising and nlarging his flora.

Dr. Moss is survived by his wife Margaret, and by two married daughers, Eleanor and Marion.

A list of his publications, which is early complete, follows:

\section{PUBLICATIONS OF E. H. MOSS}

928 Lewis, F. J., E. S. Dowding and E. H. Moss. The vegetation of Alberta. II. The swamp, moor and bog forest vegetation of central Alberta. Jour. Ecol. 16: 19-70.

932 The vegetation of Alberta. IV. The poplar association and related vegetation of central Alberta. J. Ecol. 20: 380-415.

934. Rings of cork in the wood of herbaceous perennials. Nature 133: 689-690.

936 The ecology of Epilobium angustifolium with particular reference to rings of periderm in the wood. Amer. J. Bot. 23: 114120 .

38 Longevity of seed and establishment of seedlings in species of Populus. Bot. Gaz. 99: 529-542.

40 Overwintered Giant Puff-Balls in Alberta. Mycologia 32: 271-273.

40 Interxylary cork in Artemisia with a reference to its taxonomical significance. Amer. J. Bot. 27: 762-768.

44 The prairie and associated vegetation of southwestern Alberta. Can. J. Res. C. 22 . $11-31$.
1944 Lilaea scillioides in southeastern Alberta. Rhodora 46: 205-206.

1946 E. H. Moss and W. C. McCalla. Alfred Henry Brinkman, 1837-1945. Can. FieldNat. 60: 107-108.

1947 E. H. Moss and J. H. Campbell. The fescue grassland of Alberta. Can. J. Res. C. 25: 209-227.

1949 Natural pine hybrids in Alberta. Can. J. Res. C. 27: 218-229.

1952 Rusts on Adoxa in Alberta. Mycologia 43: 99-102.

1952 Grassland of the Peace River region, western Canada. Can. J. Bot. 30: 98-.124.

1953 E. H. Moss and A. L. Gorham. Interxylary cork and fission of stems and roots. Phytomorphology 3: 285-294.

1953 Forest communities in northwestern Alberta. Can. J. Bot. 31: 212-252.

1953 Marsh and bog vegetation in northwestern Alberta. Can. J. Bot. 31: 448-470.

1955 The vegetation of Alberta. Bot. Rev. 21: 493-567.

1956 Francis John Lewis. Proc. and Trans of the Roy. Soc. Canada. Third Series 50: 103-104.

1956 Ragweed in southeastern Alberta. Can. J. Bot. 34: 763-767.

1959 Flora of Alberta. Univ. Toronto Press.

1961 Large-flowered Hemp Nettle, Galeopsis speciosa. Blue Jay 19: 33-34.

1961 E. H. Moss and G. H. Turner. Bryophytes from the Edmonton region, Alberta. Can. J. Bot. 39: $1177-1193$.

\section{Death Leads to New-born Life}

\section{by E. A. Dowson}

in memory of his wife

As death strikes home at one we loved We sink prostrate with grief, And kindly words of dearest friends Bring no heartfelt relief.

But as time eases death's sharp sting Our hallowed thoughts remain, And with undying faith we know Death leads to life again

Just as we know that Winter months When leaf and flower decay Are prelude to the flush of Spring And beauty's new-born day. 